\title{
COMPARATIVE ANALYSIS OF THE THOUGHTS OF FAHIM KHAN AND MUHAMMAD ABDUL MANNAN ABOUT THE CONCEPT OF ISLAMIC CONSUMPTION
}

\author{
Dini Puspitasari \\ Universitas Islam Indonesia, Yogyakarta \\ dinipusp17@gmail.com
}

\begin{abstract}
Increasing income at some point, the community has shifted its consumption pattern from food to non-food. This research is in response to the current phenomenon of society as well as problem solving and evaluation of the shift of public consumption patterns into modern consumption patterns due to increasing income.

The focus of this paper is about the concept of Islamic consumption from the thinking of contemporary figures, namely Fabim Khan and Mubammad Abdul Mannan. The method used is descriptive qualitative with library research and a primary source used from the book. Essays in Islamic Economics by Fabim Khan and Islamic Economics; Theory and Practice by Muhammmad Abdul Mannan.

The results of this study show that the thoughts of Fahim Khan and Mubammad Abdul Mannan have similarities on indicators of Islamic consumption balance, the concept of Islamic needs and the concept of preference in Islamic consumption. And there are differences in surveillance in Islamic consumption, namely on the institutional framework.
\end{abstract}

Keyword: Concept of Islamic Consumption, Fabim Khan, Mubammad Abdul Mannan

\section{Introduction}

Human beings are social beings whocannot live alone, who basically need the help of others in carrying out their economic activities. Economic activities that he does either in the form of physical actions, speech, or contributing to thinking, require humans to interact with other human beings. In interacting with other humans, humans need consumption to survive where the higher the need, the more consumption will increase. In addition to survival, every human being also wants to achieve a maximum and limitless level of consumption, until his desire is fulfilled as long as his income and budget are still sufficient for his expenses. What focuses here is on fulfilling an unlimited level of satisfaction to achieve maximum use in the use of goods consumed which is the greater the amount of goods consumed the greater the level of satisfaction (Basuki \&Prawoto, 2011, p. 12). 
Consumption activities are carried out in order to meet the needs. The most basic physiological need of humans in order to survive is food. However, human needs are not only limited to food commodities but also non-food commodities. Based on Susenas data in September 2019, which shows that the average indonesian spends 1,205,862 rupiah per month for food and non-food needs. Compared to September 2018, the average monthly per capita expenditure of the population increased by 4.65 percent (Larasati, 2019). With the increasing income, at some point people will shift their consumption patterns from food to non-food. Judging from the graph of average expenditure per capita per month by group of goods (Rupiah) in 2013-2019 the following:

\section{Figure 1}

\section{AveragePerCapita Expenditure Per Month By Group of Goods (Rupiah), 2013-2019}

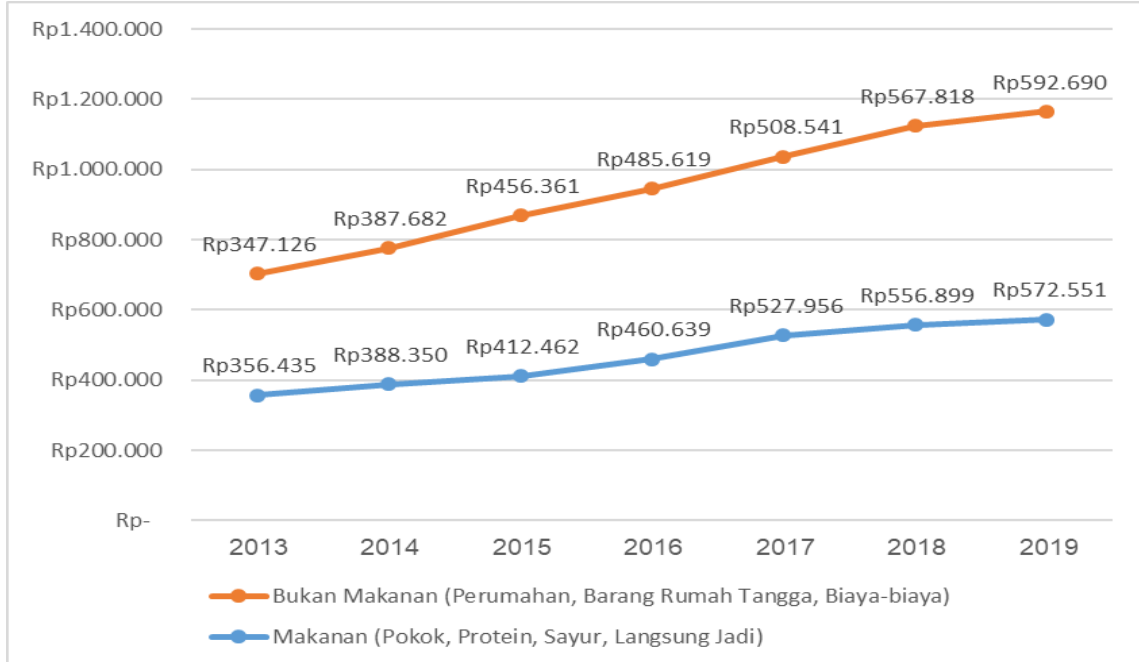

Source: Indonesian Statistical Publications

Judging from the table above if expenditures are distinguished by food commodities and not food, then the population of Indonesia in 2019 allocates more expenditures for non-food commodities. In a year, the average per capita expenditure of non-food commodities amounted to 592,690 rupiah or 50.83 percent of total expenditure. On the other hand, the expenditure used to meet food needs amounted to 572,551 rupiah. In other words, the share of food expenditure is 49.17 percent. This share of spending decreased compared to 2018 (50.08 percent).

From the explanation above, the reason for formulating the concept of Islamic consumption is nothing but an answer to the current phenomenon of society as well as problem solving and evaluation of problems that arise one example as previously presented is the shift of public consumption patterns into modern consumption patterns due to increasing income. Of course, over time, this requires a new study and a review of the 
concept of Islamic consumption in society if juxtaposed with the current situation that has certainly experienced the dynamics and social structure. Therefore, some contemporary figures give special attention to the development of islamic economic system through the concept of Islamic consumption. From here we can get to know two contemporary figures of Islamic economy, Fahim Khan and Muhammad Abdul Mannan who pay special attention to the concept of Islamic consumption.

In terms of consumption, Fahim Khan states that needs (not desires) determine consumer behavior, because it is seen from Islamic norms that needs are defined more objectively than desires. Thus, in the Islamic economy takes precedence over balance and follows the middle path as the norm, a substitute for maksimization (Khan, 2014). In another analysis, Mannan argues that Islam does not recognize the materialistic penchant for modern consumption patterns. However, Islam has the basis of consumption pattern thinking that is through the reduction of excess physiological desire arising from artificial psychological factors with the aim of freeing human energy from spiritual purposes (Khan, 2014). In another analysis, Mannan argues that Islam does not recognize the materialistic penchant for modern consumption patterns. However, Islam has the basis of consumption pattern thinking that is through the reduction of excess physiological desire arising from artificial psychological factors with the aim of freeing human energy from spiritual purposes (Mannan, 1995).

From the above explanation that Fahim Khan and Muhammad Abdul Mannan have the same scientific background, namely islamic economy. However, his scientific specialization is clearly different, so the author is interested in analyzing the concept of Islamic consumption from the thoughts of Fahim Khan and Muhammad Abdul Mannan.

\section{Review of Related Literature}

\section{Consumption in Islamic Economy}

The theory of consumption put forward by Keynes that we already know in conventional economics suggests that there is a minimum consumption expenditure that must be done by the community and the consumption expenditure will increase with increased income (Priyono \& Supriyanto, 2016, p. 42). Because in conventional economics one of the goals in consumption is to achieve maximum satisfaction and one's desire will be very closely related to the concept of satisfaction. Therefore, in conventional economics seeing between need and desire is both inseparable.

The theory that has been described above is very different from Islam, because consumption in Islam is more based on needs (needs) not to desire (wants). This difference includes differences that are momentary or lustful (Jenita \& Rustam, 2017), because Islam prohibits to consume something extravagant, wasteful and not beneficial for himself or others (Ghafur, 2016). Thus, the above statement can be used as a basis and reference in building consumer theory (in general) and consumption satisfaction and rationality of consumption (specifically) in Islam. 
The purpose of consumption in Islam is to obtain the greatest maslahah, so that it can achieve happiness and prosperity in the world and the hereafter (falab fi ad-dunya wa alakhirah). A Muslim will achieve a good level of consumption or achieve maximum satisfaction in consumption if the consumption is carried out in accordance with Islamic teachings. Because in consuming also as a means of help to worship and draw closer to Allah SWT and actually consume something with good intentions to increase strength and stamina in obedience to the command of Allah SWT will make consumption is worth worship with which people get rewarded (Almizan, 2016).

In addition to making consumption worth worship, aspects that must be seen in other consumption is maslahah (barakah) which includes aspects of halal goods / services, not only halal but also tayyib and sholeh, so in consuming in addition to fulfilling the needs also at once in the framework of worship to Allah SWT (Septiana, 2015). Therefore, as a human being and the perpetrator of consumption in increasing satisfaction there must be limits, namely in addition to budget and budget is also not miserly and excessive (tabdhir and israf). Because according to Ash-Shaibani a Muslim in consuming in sufficient conditions (kifayah) not in a condition of begging (kafafab). That is enough for himself and his family also to be used in terms of goodness (Muhammad, 2019).

\section{Construction of Islamic Consumption Thinking Biography of Fahim Khan}

His full name is Muhammad Fahim Khan, commonly referred to as Fahim Khan born in India in 1946. A Muslim thinker and economist educated in the West but very understanding that Islam as an integral and comprehensive way of life has its own economic system and value and is able to bring Muslims to an authoritative position in the eyes of the world (Aravik, 2017).

Fahim Khan's educational history is that he obtained his B.A. and M.A. in statistical sciences from Punjab University, Pakistan in 1968, then obtained an M.A. in political economics in 1977 and a Ph.D. in economics in 1978 at the same University of Boston, USA. After that he joined the Islamic Research and Training Institute (IRTI) since 1998 and held various positions such as Head of Research Division, Head of Training Division and Head of Islamic Economic Development and Cooperation Division. He also served as Director of IRTI for a year (Khan, 2014).

He also worked in various fields of teaching, training and research, namely at the Ministry of Government Planning of Pakistan (1969-1981) who served as Deputy Chief. At The International Islamic University of Islamabad, Pakistan (1981-1988) became Professor of Economics and Director of the School of Economics, and was a Guest Lecture at Pakistan's Quaid-e-Azam University, King Abdulaziz University of Saudi Arabia and the British Islamic Foundation. In addition, he also worked at the Islamic Development Bank, Jeddah, Saudi Arabia (1988-2007) as Division Head, who also achieved as an advisor in the field of Financial System Transformation at the State Bank of Pakistan (Central Bank of 
Pakistan) for two years to assist in restructuring and reforming the financial system to be adapted to Shariah. In 2007-2008 he was Professor of Islamic Finance at Daarul Hikmah,Jeddah Consultant for Al-Asr,Advisor to Jeddah and currently he works as Chairman of Riphah Center of Islamic Business at Riphah International University,Islamabad, Pakistan (Mihe, 2018).

In addition, he is also widely involved in various academic and professional organizations, such as being a member of the Editoral Board of Pakistan Institute of Development Economics, a member of the International Board of Islamic Economics Review in the United Kingdom, a member of The Board of Governors (Academic Group) at the Institute of Islamics Banking and Insurance, Uk. He has also been a member of the Commission in Transformation of Financial System in Pakistan. A large number of papers have been presented at various International Seminars and Conferences and received grants from international institutions for research projects on international labor migration and other projects on channel procedures and international trade payments, he also received grants from national institutions for demographic research (Khan, 2014).

Fahim Khan is a contemporary figure in economics who has 39 years of experience in economic policy and planning, teaching and training, institutional capacity building, research and in providing advice and consultation. As an academic, Fahim Khan also guided and tested a large number of thesis Ph.D., M.Phil. students. and M.Sc. from universities in Pakistan, The United Kingdom, Australia, Malaysia and Nigeria. As well as active in reviewing articles in various international journals in the field of economics and finance.

\section{Fahim Khan's Background in Thought}

During his professional career, Fahim Khan intensively and extensively pursued various fields, including economic development, foreign trade and international economics, finance and banking, investment and financial analysis, international labor migration, Islamic economics and finance, statistics and econometrics. Fahim Khan became active in writing, writing 10 books and monographs in islamic economics, banking and finance published in Pakistan, Saudi Arabia and the United Kingdom. He also has 11 journal publications and 20 other works in various reading books and proceedings seminars and conferences from different parts of the world. It is also added with many research reports and policy papers published for the benefit of the government when he worked at the Ministry of Planning, Pakistan (Khan, 2014).

Judging from the field pursued by Fahim Khan, he has basic objectives and assumptions in publishing his works, namely: 1) show that an Islamic economy is viable (lasting; it can survive), and will not face irregularities if it is run in accordance with Islamic teachings. 2) demonstrate that the Islamic economy has the ability to be analyzed in detail and thoroughly as conventional economics, not only by demonstrating its capabilities, predicting and controlling policy. But it is also its ability to be compared with paradigms and economic views. 3) a comprehensive study of Islamic economics in political, 
philosophical and ethical aspects, can hardly be done at once given the multi-disciplinary nature of the task at the same time. However, some experts need steps and methods to realize that goal.

That is the background of Fahim Khan's thinking, it can be concluded briefly that Fahim Khan in his literature conveys the importance of the consequences of islamization of the economy, namely by offering demonstrations of the viability of Islamic reform in all sectors of the contemporary economy.

\section{Biography of Muhammad Abdul Mannan}

Muhammad Abdul Mannan was born in Bangladesh in 1918 and he is married to Nargis Mannan who holds a master's degree in political science, and has two daughters and a son named Reshmi and Ghalib. Mannan is an Islamic economic figure who voiced the establishment of theMuslim World Bankin the five years before the establishment of the Islamic Development Bank (IDB) in 1975 in Jeddah, Saudi Arabia (Aravik, 2017).

In his educational history Mannan obtained a mater degree in economics from Rajshahi University in 1960. In 1970 Mannan continued his studies at Michigan State University, USA for the M. A. (economics)program. After obtaining his M.A. (economics) in 1973, he continued his studies in doctoral programs in industry and finance at the same university, in economics, namely educational economics, development economics, industrial relations and finance.

Mannan's work experience has gained since receiving a master's degree in economics, where he worked in various government economic offices in Pakistan, including being an assistant leader at The Federal Planning Commission of Pakistan in the 1960s. And after completing his doctoral program, Mannan became a senior lecturer and actively taught at Papua New Guinea University of Tehcnology and was appointed assistant dean. In 1978, he was appointed professor at the International Centre for Research in Islamic Economics, King Abdul Aziz University in Jeddah, Saudi Arabia. During this period Mannan was also active as a visiting professor at the Moeslim Institute in London and Georgetown University in the United States. Through his long academic experience, Mannan decided to join the Islamic Development Bank (IDB) and become a senior Islamic economist at IDB since 1984 (Muhammad, 2019).

Some of Abdul Mannan's works are Islamic Economics, Theory and Practice, Delhi, Sh.M. Ashraf, 1970, which became the first textbook for most students and scholars of Islamic economics. Because in the 1970s Islamic economics was recently looking for its formula and Mannan managed to elaborate quite fully and context on the framework and specific characteristics of Islamic economics, which in line with the purpose of the book is to provide a thorough view of Islamic economic values in the context of contemporary economic analysis.

Muhammad Abdul Mannan is a contemporary figure in Islamic economic thought who during his 30 -year career has played a large role in a large number of educational and 
economic organizations. For contributing to the development of Islamic economic studies, one of which is from his first book Islamic Economics: Theory and Practice, he received an award from the Pakistani government as the Highest Academic Award of Pakistan in 1974 equivalent to the Pulitzerprize (the highest award in print journalism in the United States).

\section{Background of Muhammad Abdul Mannan's Thoughts}

During his doctoral program in industry and finance, Mannan expressed his opinion on Western economics, especially the "Mainstream" economy which is evidence that he uses a "Mainstream" economic approach in his understanding of Islamic economics. Therefore, Mannan has some basic assumptions in Islamic economics, namely (Muhammad, 2019). First, Mannan does not believe in theharmony of interests formed by market mechanisms such as Adam Smith's theory, because basically every human being has an instinct to master on the other. If this desire is not controlled, it will harm others. Mannan thus emphasized the need for several types of market interventions in order for the Islamic economy to work on the intersection between market mechanisms and centralized planning.

Second, Rejection of Marxists, because Marxists tend to ignore fitrah human instincts. And only the Islamic economy can provide better change because it has ethical values and motivational abilities. Third, The need to break away from the paradigm of positivity neoclassicals, stating that observation should be directed to historical data and revelations. Mannan pays great attention to the norms of revelation in every observation of his economy. Which is also in line with the Islamic economy built from the main foundation of the evidences syara' which serves as revelation. Thus, all economic observations that leave the revelation will lose the spirit of the Islamic economy.

Fourth, Rejection of the idea of producer power or consumer power that later gave rise to dominance and exploitation. Mannan proposes the need for a balance between government control and competition by upholding values and norms in line with sharia. Fiveth, Mannan argues that Islam allows private ownership as long as it is subject to moral and ethical obligations. He also explained the prevailing norms that wealth should not be concentrated on the rich alone, but zakat and shadaqah also play an important role in its disribuive role, so that no capitalist understanding leads to individualism in the Islamic economy.

Sixth, Develop Islamic economics by determining basic economic functions that include three functions, namely consumption, production and distribution. There are five basic principles in sharia consumption function for basic economic functions, namely righteousness, cleanliness, moderation, beneficence and morality.

\section{Study Method}

This research is library research, which is literature research. Using descriptive qualitative writing methods, with the primary reference source of the book of two 
contemporary figures of Islamic economics, Fahim Khan with the title of his book Essays in Islamic Economics and Muhammad Abdul Mannan with his book entitled Islamic Economics; Theory and Practice. In addition, is also taken from secondary references in the form of books, journals, news and others that discuss the concept of Islamic consumption. The main discussion is the concept of Islamic consumption from the thoughts of two contemporary figures of Islamic economics Fahim Khan and Muhammad Abdul Mannan. The purpose of this study is to compare the thoughts of the two figures whose focus is on the concept of Islamic consumption.

\section{Results and Discussion}

\section{Fahim Khan's Thoughts on Islamic Consumption}

\section{Islamic Consumption Framework}

In the process of determining consumer choice in the field of commodities (commodity space) there are unknown choices in the normal capitalist theory of consumer behavior, such as the achievement of consumer satisfaction in fulfilling its wishes. However, Islamic Economics provides a different analytical framework, namely that desire cannot be a driving force for consumer behavior in Islam. Therefore, alternatives are needed as a basis for consumer behavior before stepping into the field of commodities (commodity space), namely (Khan, 2014):

First, consumption and income are spent for worldly needs and for the way of Allah(infaq fi sabilillah). Spending in the way of Allah here according to Fahim Khan is an expenditure that is not in the interests of the world. Because the consumer has two baskets in consumption, namely basket $\mathrm{X}$ and $\mathrm{Y}$. Basket $\mathrm{X}$ contains expenses to meet worldly needs, and basket $Y$ contains expenditures in the way of God. Both expenditures cannot be treated the same as the choice between commodities within the normal capitalist framework.

If it is assumed that the consumer expenditure budget starts at point $\mathrm{A}$, the reward of each expenditure on the $\mathrm{Y}$ basket is higher than the worldly satisfaction obtained from the same expenditure on basket X. Although the manufacturer cannot start from A, he then spends his entire budget on the $\mathrm{Y}$ basket because there is a minimum value of $\mathrm{X}$ that must be met for the needs of life. It can be said that it is the best point and cannot be identified using conventional analysis, because only the choice between the two commodities can point to the best point. In accordance with the shari'ah written in the Qur'an at surah AlIsra [17]: 29:

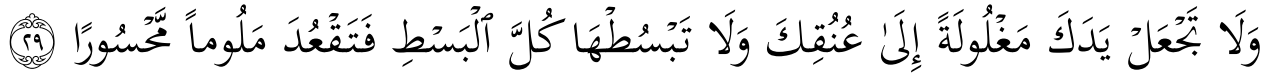 \\ "'And donot put your hand chained to your neck, nor stretch it out too much, lest you become blameworthy andregretful.","}

The conclusion that can be drawn from the above discussion is that the rules of balance are fundamental rules in terms of Islamic economics, and that is comparable to the 
maksimization rules in terms of capitalist economics. This balance rule while keeping individuals in a mid-position called Iqtishad.

Second, consumption for now and that must be saved for later consumption. Conventional economic views explain the truth of the existence of interest in the concept of savings. Because savings and consumption are currently determined by equatingthe rate of time preferenceand interest rate. But in reality, people will still save even if they don't get any interest, their saving habits increase or decrease without being affected by the ups and downs of interest rates. And this is the factor of difference and variation of one's saving motives, because only a small percentage of them have a motive to earn income from savings.

Islamic economic view is clearly different in the concept of saving, there are two aspects of choice between consumption and saving according to islamic perspective, namely (Khan, 2014): First, Saving for future consumption purposes. Saving for this purpose is very permissible and recommended, because it is the teaching of the prophet Muhammad SAW that it is better to leave a sufficient offspring than the poor. In saving, it is not necessary to maximize behavior, but the principle of balance is necessary because according to the word of Allah in surah Al-Furqan [25]: 67 who recommends being in the middle of spending wealth, not excessive nor miserly:

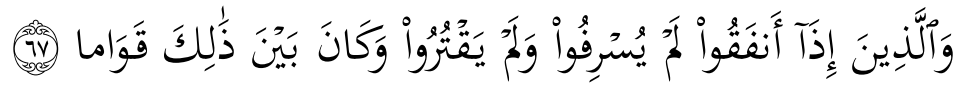

"And those who, when they spend, are neither extravagant nor niggardly, and are in the midst of such a thing"

Second, The expected rate of return from savings. The motivation of saving in terms of Islam is not interest rates, but rather helping those in need. Because a Muslim must pay zakat for his savings, with the existence of zakat savings only make sense if the savings generate income, so that zakat can be paid from the income. The more a person earns wealth, the more his savings and the more able he is to fulfill his obligations from the savings (zakat), without affecting his own savings. Thus, the expected rate of return savings plays a positive role in driving savings.

In terms of Islam a saver will become an investor at the same time. That indicates the absence of a saving-investment gap and ultimately leads to the determination of the expected macroeconomic balance. Third, the fundamental element of the Islamic framework is not normative, but is a positive assumption. The positive assumption is that Islam understands that man has certain needs, so more important needs must be met first after that followed by the fulfillment of less important needs. Because rational human beings do not treat all their desires equally importantly, on the contrary it is the primary need that determines the priority among some desires. 


\section{Vol 7 No 2: Agustus 2020. 63-80 \\ ISSN: 2460-9889 (Cetak) \\ ISSN: 2580-3565 (Online)}

\section{Concept of Necessity in Islam}

Needs and desires have their own value concept, if the desire is determined by the concept of utility, then the needs in the Islamic perspective are determined by the concept of maslahah. The welfare of mankind (maslahat al-ibad) is the purpose of the concept of shari'ah. Therefore, all goods and services that affect maslahah can be called the needs of mankind. The concept of utility as the ability of goods / services in fulfilling human desire and satisfaction is determined subjectively. Because every economic activity that is done to obtain or produce something must be driven by the utility of the goods and each individual determines his satisfaction with his or her own criteria.

According to Syatibi, maslahah is a basic element and purpose of human life in the world that affects the ability of a goods / services in its fulfillment. Syatibi provides five basic safeguards in human life, namely religion, physical self, reason, descent and wealth. The existence of maslahah for humans is shown when goods / services have the ability to support these five elements and that is what is meant by necessity. Not all needs have the same importance, but here are three different levels of need, namely (Khan, 2014): 1) When the five fundamental elements are only slightly protected. 2) When the protection of the five fundamental elements is completed or strengthened. 3) When the five fundamental elements are not only guaranteed but also improved and embellished.

From the three levels of needs above, it can be said that all goods and services have the ability or quality to encourage the five fundamental elements are said to have maslahah namely by protecting, strengthening, equipping, improving and beautifying. Therefore, the goods / services that protect the five fundamental elements will have a larger maslahah, followed by goods / services that strengthen it, improve it and encourage all five.

\section{Allocation of Resources for Needs}

There are three basic principles in allocating resources, namely the first and most important to be allocated is dharuriyyat, after which if it still has the remaining resources can complete the complementary items that are hajiyyat, and when it is fulfilled can be allocated to improve or beautify that is to tahsiniyyat. This basic three-principles sorting is second-level preference sorting in all three categories of needs. In this matter the concept of inference can be applied, but in dharuriyyat and hajiyyat it cannot describe the sorting of preference to produce a smooth indeferens curve. In contrast to tahsiniyyat that may be able to form a sequence of preferences, indicated in a convex and smooth curve of indeferens. In addition, all preferences do not forget to stick to the rules of balancing until there is no room to be extravagant, israf and tabdzir.

It can be concluded the difference if using the concept of meeting the needs, not maximizing satisfaction in fulfilling the desire seen in: 1) Nature of the Problem. The problem lies in the scarcity of resources, while economic activities aim to maslahah (welfare) in the world and the hereafter. And all activities that have maslahah called needs, and needs must be met. To solve this problem man must meet his needs instead of satisfying the 
desire, because this infinite desire can result in scarcity of these resources. 2) Concept of Efficiency. Efficiency in economic problems is said to be efficient if maximizing in meeting the needs with existing resources, not maximizing satisfaction. Efficiency has the same attention as the fondness (desirability)and the desirability is determined by maslahah.

Here are some aspects of the consequences of consumer behavior in terms of Islam, stated in the following figure:

Figure 2

\section{Muslim Consumer Choice Choices Facing}

First-Rate Consumers

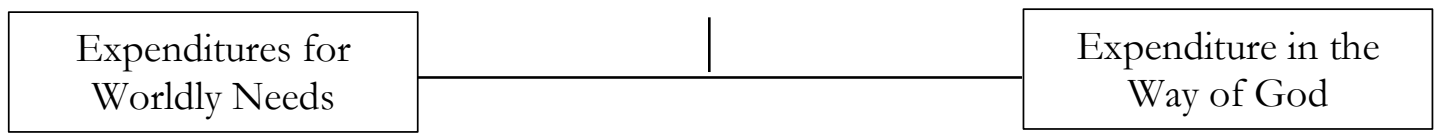

\section{Second-Tier Options}

Consumption Later

Current Consumption

\section{Third-Tier Options}

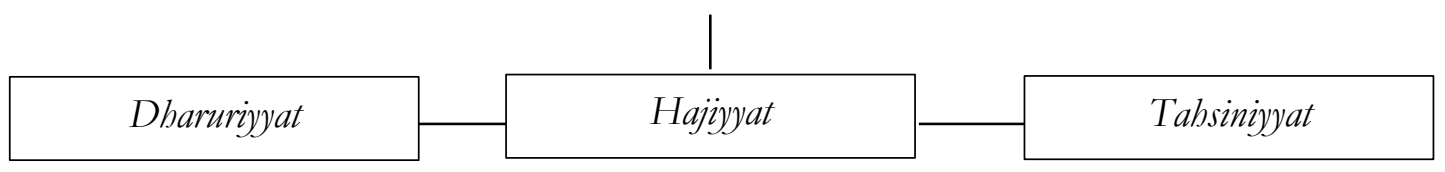

Third-Tier Options

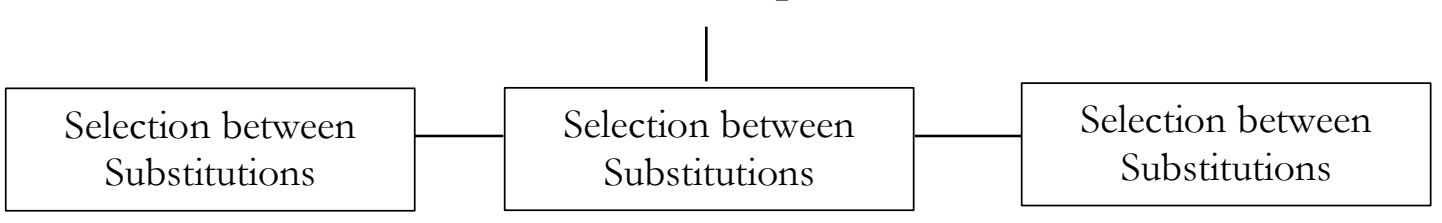

Source: Fahim Khan, 2014

From the picture above can be seen, that the theory of consumer behavior in terms of Islam should analyze the four levels above, unlike conventional economics that only limit itself to the second and fourth tingakt only. Thus, the scope of consumer behavior theory in the framework of Islam is much wider than the conventional framework.

\section{Maslahah dan Utility}

Maslahah is a more objective concept than utility in analyzing the behavior of an economic actor. Although if seen maslahah and utility have similarities, but there are differences between the two, namely First, Maslahah is subjective, but in the sense that consumers are the best judge in assessing whether a goods / services have maslahah for him, the criteria do not make the maslahah subjective. Instead, utility is something that is hollow and depends on individual thinking. Second, Maslahah individual will be consistent 
with social maslahah, unlike individual utilities that are often contrary to social utility. That is because there are no shared criteria regarding utilitydetermination, because individual satisfaction with a particular desire may not be desired by many masarakat. Third, The concept of maslahah as the basis of all economic activities of the community and is the basic purpose of consumption, production and distribution. Thus, it does not make utility as a consumption and profit destination as a production goal. Maslahah remains the goal of both economic activities for individuals and countries. Fourth, Comparison between utility obtained by consumers because consuming goods can not be given objectively, even though the goods and amounts consumed are the same. In contrast to maslahah, comparisons between different maslahah tingakat may be done. Because it can be seen who is more in need and the consequences of the activity, which one produces a greater maslahah.

\section{Institutional Framework}

The market as a designated institution within the conventional framework, used by consumers to achieve its goals in a capitalist economy. The market also needs an Islamic economy to limit the freedom of consumer behavior. On the other hand, consumers may not have a tendency to achieve their maslahah, but instead do israf and tabdzir. For example, consumers who eat full and get satisfaction while their neighbors are starving. A consumer may focus on fulfilling dharuriyyat, hajiyyat and tahsiniyyat related to nafs (physical self) or maal (property), but not paying attention to dharuriyyat for diin (religion), 'aql (reason) or nasl (offspring), it is also the same as consumers who consume conspicuously but under the pretext of achieving tahsiniyyat.

Therefore, shariah purposes as above can include the following institutions: 1) Voluntary institutions developed through sharia education and training intended for everyone. 2) Law enforcement agencies that require individuals to refrain from activities that create social and economic chaos in society.

With the establishment of the above two institutions, it is expected: First, not only encourage to train self-resilience and submit to Islamic principles, but also develop voluntary social institutions in controlling individual behavior. Second, at the same time can intervene in activities, such as consumption of prohibited goods, conspicuous consumption, excessive consumption (israf)as well as deviations over inconsistent behavior in Islamic principles. Thus, in the Islamic economy, non-market institutions must play an important role along with market institutions.

\section{Muhammad Abdul Mannan's Thoughts on Islamic Consumption}

\section{Consumption Process}

Mannan defines consumption as demand, however, the meaning that depends on it is very broad although it is described briefly. Because everything about consumption is the primary thing and consumption in Islam has a different approach, namely in meeting the needs that do not put forward materialistic in modern consumption patterns. Mannan 
divides the form of consumption into three parts, namely: individual consumption, social consumption on the basis of God and investment for the grip of future life(Mannan, 1989).

In addition, Mannan also associates the process of consumption with income, personal consumption, consumption for the family, consumption for social, zakat and shadaqoh. This approach is called the consumption function in Islam whose variables are identified with Sharia rooted in the Qur'an and Sunnah (Mannan, 1984).

All parts of consumption from the process to its function must be managed in accordance with the principles and values in Islam. So that there will be maintained stability and balance (tawazun) economy. With that the creation of the concept of fairness in the distribution of income, which is the center of economic growth and development, in addition to the creation of the concept of simplicity of consumption (moderation)to prevent misoliness and miserliness.

\section{Principles of Islamic Consumption}

Islam seeks to reduce the material needs of various human beings. With the aim of producing human energy in pursuit of his spiritual ideals. Therefore, Islamic provisions on consumption are controlled in five principles, namely justice(righteousness), cleanliness, simplicity (moderation), nerosity (beneficence) and morality (morality). Here is a further explanation of the five principles (Mannan, 1995): First, Principles of Justice. Justice is one sign of the balance of consumption in the Islamic economy. Prinsp kedilan in consumption is written in the Qur'an surah al-Baqarah [2]: 168, namely:

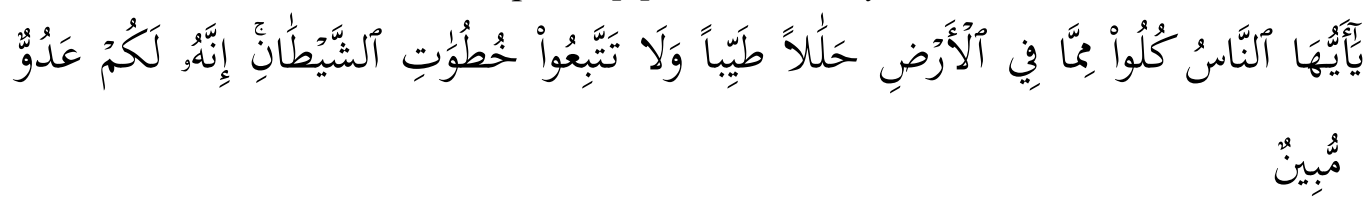

"O mankind, eat of what is lawful and good from what is on the earth, and do not follow the footsteps of Satan; for satan is a manifest enemy to you."

In the verse above means double about seeking sustenance lawfully and not prohibited by law. In the case of food and drink that is forbidden in Islam is blood, carcasses of animals that have died themselves, pork and star meat that when slaughtered do not mention the name of God as a material of worship and offerings to gods other than Allah. The first three classes are forbidden because these animals are harmful to the body and the soul, while the last two prohibitions are prohibited because they are directly related to the same moral and spiritual harm as associating god. However, there is leeway for people who are forced to eat the forbidden food, but only considered necessary for the needs of the time alone.

Second, Hygiene Principles In this principle the food and drink consumed by a Muslim should be good or suitable to eat, not dirty let alone disgusting so as to spoil the taste buds. Therefore, not everything that is allowed to be eaten and drunk can be consumed in all circumstances, but from all that is allowed only clean and useful food and 
drinks. In accordance with the Sunnah of the Messenger of Allah which states that cleanliness is part of the Faith, thus Islam attaches great importance to cleanliness. In addition to clean food must also be halal, not enough halal but also must tayyib, because by consuming halal food and tayyib is one form of faith in God.

Third, Principles of Simplicity. The simplicity here does not mean destitute and stingy, nor does it mean literally simple in lifestyle. But the hereality means avoiding eating and drinking excessively, thus showing adequate consumption behavior and according to the needs of not israf and tabdzir. As written in the Qur'an at surah Al-A'raf [7]: 31::

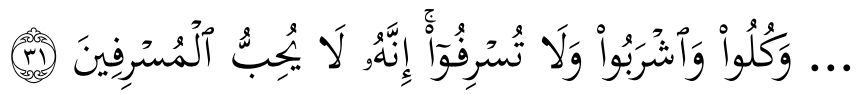

"... eat and drink, and do not be extra extra. Surely Allah does not love the extra-believers."

The significance of the verse above is that lack of food and drink can affect the development of the soul and body, similarly if the stomach is filled beyond the capacity that can be accommodated that is excessive will certainly affect the health of the body and soul. Because all the sources of disease come from the stomach, which is seen from what is eaten and drunk. Therefore, Allah says that man knows himself from exaggeration, as well as the practice of incarnate certain types of food with the consideration of individuals, strictly not allowed in Islam.

Fourth, Principles of Generosity There is no harm or sin when consuming lawful food and drink that Has been prepared by Allah because of His generosity. And if you are in a state of disquiality, then surely Allah is All-Forgiving, All-Wise. In this case there is a gradual displacement that is elastic and takes into account the purpose of direct consumption and basic consumption. Therefore, dangerous foods and beverages such as intoxicating are prohibited, because although consumed in the slightest amount will be harmful, unless used as a remedy to save lives.

Fiveth, Principles of Morality. The ultimate goal of consumption is not just about direct food and drink, but actually to promote and advance moral and spiritual values. Thus a Muslim is taught to mention the name of Allah before and after meals which is interpreted as a reminder of the gratitude that He has given, namely by a statement of gratitude to Him. This is so that a Muslim feels a divine presence when he fulfills his physical desires when eating and drinking. In addition, there are also some things that are forbidden such as alcohol, because the danger it poses is greater than the enjoyment it obtains, because it tends to cause discord and hostility that eventually abandons prayer and forgets the remembrance of Allah. Thus this becomes an important thing, because Islam wants a combination of material and spiritual living values that are happy and harmonious.

\section{Needs and Order of Priorities in Islam}

Man in consumption will meet his needs, here there are three parts of human needs, namelynecessities, pleasure (comforts)and luxury (luxuries)described as follows (Mannan, 1995): 1) Necessity is all that is needed and becomes a basic need that must be met. 2) 
Pleasure is defined as a commodity whose use aims to increase worker efficiency, but in fact is not balanced with the cost of commodities incurred. 3) Luxury is defined as a commodity whose use does not increase worker efficiency, even tends to reduce it. Luxury for most people is like jewelry, cars, clothes and houses like palaces.

Regarding the order of priority there are two issues discussed in Islamic teachings. The first issue, about food and drink should follow the guidance as discussed in the principle of consumption before this. The second issue is whether the Islamic state should encourage the production of luxury goods within the current socially capitalistic framework of the Islamic State. A think-provoking madzhab argues that the Islamic state today cannot be encouraged to produce luxury goods because their use does not add efficiency, even tends to minimize it.

The above opinion is not as strong as it seems, it ignores the important fact that all work depends oneffective demandand it is not possible to increase the level of need and pleasure that exists unless first take steps to transfer the purchasing power that is now in the rich to the poor in large numbers. By simply banning the production and consumption of luxury goods without the even distribution of wealth and income, it may not ease the economic problems of society.

Economically not all consumption of luxury goods is wasted. The truth of this opinion is that it depends relatively on the existence of the capitalist structure of Islamic countries characterized by uneven distribution of income, due to the presence of monopoly elements with different levels in all sectors of the economy, especially in the undeveloped Islamic countries. Therefore, if the economic structure changes and the economic system of society is more evenly arranged based on Islamic values, then the production factors that are now used in the luxury goods industry will automatically be diverted to the production of useful commodities so that effective demand will be high.

\section{The Nature of Consumer Behavior}

In analyzing the behavior of Muslim consumers, one can be narrow-minded and static by saying that Muslim consumers are only led by many prohibitions, because in Islam all prohibitions have a definite truth, then Muslim consumers are forbidden to sort their hearts to eat foods that are forbidden for the sake of social discipline, Islamic unity and spiritual value.

But Mannan views "not excessive attitudes" in terms of consumption led by the behavior of Muslim consumers who put the interests of others first. This dynamic concept of moderate attitude in consumption is the key in understanding muslim consumer behavior. In fact consumption in Islam is a positive understanding. Therefore, islamic prohibitions on food and drink should be seen as an attempt to improve consumer behavior. 
Comparative Analysis of The Concept of Islamic Konsusmi Fahim Khan and Muhammad Abdul Mannan

Table 1

Comparative Analysis of Islamic Consumption Concepts Fahim Khan dan Muhammad Abdul Mannan

\begin{tabular}{|c|c|c|c|}
\hline & \multicolumn{2}{|c|}{$\begin{array}{l}\text { COMPARATIVE ANALYSIS OF ISLAMIC CONSUMPTION } \\
\text { CONCEPT }\end{array}$} \\
\hline & & FAHIM KHAN & MUHAMMAD ABDUL MANNAN \\
\hline \multirow[b]{2}{*}{ 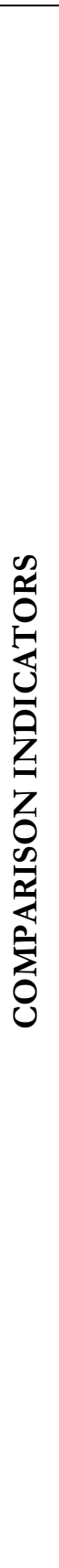 } & $\begin{array}{c}\text { LANCE OF } \\
\text { ISLAMIC } \\
\text { CONSUMPTION }\end{array}$ & $\begin{array}{l}\text { 1. Islamic Consumption } \\
\text { Framework } \\
\text { a. Consumption for worldly } \\
\text { needs and for God's way. } \\
\text { b. Consumption for now and } \\
\text { for later consumption. } \\
\text { c. The Islamic framework is } \\
\text { not normative but is a } \\
\text { positive assumption }\end{array}$ & $\begin{array}{l}\text { 1. Consumption Process } \\
\text { a. Individual consumption } \\
\text { b. Social consumption on the basis of } \\
\text { God } \\
\text { c. Investment for the grip of future life }\end{array}$ \\
\hline & $\begin{array}{l}\text { CONCEPT OF } \\
\text { NEED IN ISLAM }\end{array}$ & $\begin{array}{l}\text { 2. Concept of Necessity in } \\
\text { Islam } \\
\text { The need in Islam is } \\
\text { determined by the concept } \\
\text { of maslahah,namely as five } \\
\text { basic safeguards in human life } \\
\text { consisting of care: } \\
\text { religion(diin) ,physical } \\
\text { self(nafs), reason(aql), } \\
\text { descent(nasl) and } \\
\text { property(mal). Therefore, } \\
\text { maslabab is meant by necessity. } \\
\text { 3. Allocation of Resources } \\
\text { for Needs } \\
\text { a. Dharuriyat,the first and } \\
\text { most important and most } \\
\text { important level to be } \\
\text { allocated. } \\
\text { b. Hajizyat, the second level } \\
\text { that becomes } \\
\text { complementary in } \\
\text { meeting the needs. } \\
\text { c. Tabsiniyyat, the final level } \\
\text { that can be allocated to } \\
\text { improve and beautify. }\end{array}$ & $\begin{array}{l}\text { 2. Needs \& Order of Priorities in Islam } \\
\text { Human needs in Islam: } \\
\text { a. Necessities, all necessary things and } \\
\text { become basic needs that must be } \\
\text { met. } \\
\text { b. Pleasure (comforts), commodities } \\
\text { whose use aims to increase the } \\
\text { efficiency of workers. } \\
\text { c. Luxury (luxuries), commodities } \\
\text { whose use does not increase the } \\
\text { efficiency of workers, even tend to } \\
\text { reduce it. } \\
\text { Two order of priority in Islam: } \\
\text { a. Not all consumption of luxury } \\
\text { goods is wasted. } \\
\text { b. If the economic structure changes } \\
\text { and the economic system of } \\
\text { society is more evenly arranged } \\
\text { based on Islamic values, then the } \\
\text { production factors that are now } \\
\text { used in the luxury goods industry } \\
\text { will automatically be diverted to } \\
\text { the production of useful } \\
\text { commodities so that effective } \\
\text { demand will be high. }\end{array}$ \\
\hline
\end{tabular}




\begin{tabular}{|c|c|c|}
\hline $\begin{array}{c}\text { CONCEPT OF } \\
\text { PREFERENCE } \\
\text { IN ISLAMIC } \\
\text { CONSUMPTION }\end{array}$ & $\begin{array}{l}\text { 4. Maslahah \& Utility } \\
\text { a. Maslahah is subjective, } \\
\text { consumers can assess goods } \\
\text { / services that have maslahah } \\
\text { for him. Utility is something } \\
\text { that is hollow and depends } \\
\text { on individual thinking. } \\
\text { Maslabah individual will be } \\
\text { consistent with social maslahah, } \\
\text { unlike individual utility as } \\
\text { opposed to social utility. } \\
\text { Maslahah as the basis and } \\
\text { purpose of economic activities } \\
\text { (consumption, production and } \\
\text { distribution), not make utilty as } \\
\text { the purpose of consumption and } \\
\text { profit as a production goal. } \\
\text { d. Comparison between different } \\
\text { levels of maslabah may be } \\
\text { done. Comparisons } \\
\text { between utilities cannot be } \\
\text { given objectively. }\end{array}$ & $\begin{array}{l}\text { 3. Principles of Islamic Consumption } \\
\text { a. Principle of justice (righteousness) } \\
\text { b. Principles of cleanliness (cleanliness) } \\
\text { c. Principle of simplicity (moderation) } \\
\text { d. Principle of generosity (beneficence) } \\
\text { e. Morality principle } \\
\text { 4. The Nature of Consumer Behavior } \\
\text { a. It is forbidden to follow the heart to } \\
\text { eat foods that are forbidden for the } \\
\text { sake of social discipline, Islamic } \\
\text { unity and spiritual value. } \\
\text { b. Holding an attitude is not excessive } \\
\text { in terms of adequate and not } \\
\text { moderate consumption. } \\
\text { c. Put the interests of others first. }\end{array}$ \\
\hline $\begin{array}{c}\text { SURVEILLANCE } \\
\text { IN ISLAMIC } \\
\text { CONSUMPTION }\end{array}$ & $\begin{array}{l}\text { 5. Institutional Framework } \\
\text { a. Voluntary institutions } \\
\text { developed through sharia } \\
\text { education and training } \\
\text { intended for everyone. } \\
\text { b. Law enforcement agencies } \\
\text { that require individuals to } \\
\text { refrain from activities that } \\
\text { create social and economic } \\
\text { chaos in society. }\end{array}$ & \\
\hline
\end{tabular}

Source: Research data processed

\section{Conclusion}

Based on the discussions outlined above, it can be concluded that; First,according to Fahim Khan the theory of Islamic consumption provides a positive theory within the framework of Islamic norms, namely with a needs-based approach where ethics, norms and sharia is manifested in practice, in addition to also prefer mashlahah rather than utility in meeting the needs and with the supervision of institutions can control individual behavior. Second,Mannan's rationale on consumption patterns in Islam is to reduce the excess physiological desire arising from artificial psychological factors with the aim of freeing human energy for spiritual purposes, by fulfilling the principles of consumption, namely 
justice, cleanliness, simplicity, generosity and morality. Untilconsumption is guided by a moderate attitude and prioritizes the interests of other oran. Thus, showing that the thinking of Fahim Khan and Muhammad Abdul Mannan has similarities from indicators of islamic consumption balance, the concept of Islamic needs and the concept of preference in Islamic consumption, and there are differences in supervision in Islamic consumption, namely on the institutional framework.

\section{BIBLIOGRAPHY}

Almizan. (2016). Konsumsi menurut ekonomi islam dan kapitalis. Al Masraf (Jurnal Lembaga Keuangan Dan Perbankan), Vol. 1, 13-30.

Aravik, H. (2017). Sejarah Pemikiran Ekonomi Islam Kontemporer. Kencana.

Ghafur, A. (2016). Konsumsi dalam Islam. Iqtishodiyah : Jurnal Ekonomi Dan Bisnis Islam, 2(2), 17-42. https://ejournal.inzah.ac.id/index.php/iqtishodiyah/article/view/213

Jenita, \& Rustam. (2017). Konsep Konsumsi Dan Perilaku Konsumsi Islam. Jurnal Ekonomi Dan Bisnis Islam UIN Imam Bonjol, 2(1), 75-84.

Khan, F. (2014). Esai-Esai Ekonomi Islam. Rajawali Pers.

Larasati, W. (2019). Ringkasan Eksekutif Pengeluaran dan Konsumsi Penduduk Indonesia. BPS RI. https://doi.org/10.22146/mgi.35166

Mannan, M. A. (1984). The Making of Islamic Economic Society : Islamic Dimensions in Economic Analysis (1st ed.). International Association of Islamic Banks.

Mannan, M. A. (1989). Economic Development and Social Peace in Islam. Ta-Ha Publishers.

Mannan, M. A. (1995). Teori dan Praktik Ekonomi Islam (M. Nastangin (ed.)). Dana Bhakti Wakaf.

Mihe. (2018). Dr. M. Fabim Khan. The Markfield Institute of Higher Education.

Muhammad. (2019). Sejarah Pemikiran Ekonomi Islam. UII Press.

Priyono, \& Supriyanto. (2016). Teori Ekonomi Makro. Zifatama Publishing.

Septiana, A. (2015). Analisis Perilaku Konsumsi Dalam Islam. Dinar: Jurnal Ekonomi Dan Keuangan Islam, 2(1). https:/ / doi.org/10.21107/DINAR.V2I1.2688 